GOMBOS Péter

Kaposvári Egyetem Pedagógiai Kar Magyar Nyelvi és Kultúratudományi

Tanszék

ORCID: 0000-0002-8172-0557

gombos.peter@ke.hu

CSIMA Melinda

Kaposvári Egyetem Pedagógiai Kar

Pedagógia-Pszichológia Tanszék

ORCID: 0000-0001-8361-6385

\section{A digitális bennszülöttek} olvasási kedve, olvasáshoz való viszonya a 2017-es és 2019-es felmérések tükrében ${ }^{1}$

Bár nem csupán a szakemberek számára mutatnak érdekes adatokat, mégsem készítenek nagy gyakorisággal reprezentativ olvasásfelmérést Magyarországon. Az ok természetesen prózai: egy-egy ilyen kutatás jelentős erőforrásokat igényel. Az, hogy az elmúlt három évben kétszer is elvégezhettünk ilyen vizsgálatot, már csak ezért is nagy jelentöséggel bír, de más okból is.

Tanulmányunkban nem azt tüztük ki célul, hogy a legutolsó mérés eredményeit minél teljesebben megmutassuk, azokat elemezzük. Mi arra vállalkoztunk, hogy egy speciális területet veszünk górcső alá. A kutatásnak azokat az adatait emeltük ki, amelyek igazolhatták, igazolják azt a feltételezést, hogy a digitális kor gyermekei másképp és mást olvasnak.

Mindenekelött szakirodalmi források segítségével írjuk le azt a klasztert, amelyet később aztán a vizsgálat adatai is jellemeznek. Mivel az elmúlt húsz-huszonöt évben 3-5 év különbség is komolyabb eltéréseket jelentett a korosztályok között, csak friss, jórészt 2010 utáni forrásokra támaszkodhattunk.

Az elméleti háttér után röviden leírjuk a Fővárosi Szabó Ervin Könyvtár pályázatának keretében zajlott kutatás legfontosabb paramétereit, majd elemezzük az itt nyert adatokat. (Nemegyszer összehasonlítva azokat az ugyanezen projekt során végzett korábbi, illetve mások által elvégzett, ismertetett vizsgálatokkal.)

Mivel nem csupán egy reprezentatív vizsgálat eredményeit szándékoztunk megosztani, írásunkban bemutatunk két, jellemzően 21. századi „jelenséget” is: a könyves közösségi oldalak és a jórészt online megjelenő fanfictionök múködését, megjelenését napjaink kultúrájában.

Kulcsszavak: olvasásfelmérés, digitális bennszülöttek, fanfiction

Tanulmányunkban friss hazai felmérések eredményeire - a 2017-es, s még inkább a 2019-es, „Az én könyvtáram” című EFOP-pályázat keretében elvégzett kutatás - és szakirodalmi forrásokra támaszkodva szeretnénk bemutatni a magyar gyermekek, különösen az iskoláskorúak viszonyát az olvasáshoz, a könyvekhez. Ahogy azt a cím is sugallja,

\footnotetext{
${ }^{1}$ A tanulmány a Múzeumi és könyvtári fejlesztések mindenkinek címú, EFOP-3.3.3-VEKOP-16-2016. azonosítószámú pályázati konstrukció keretében megvalósuló, „Az én könyvtáram” címú kiemelt projekt keretében készült.
} 
mindezt az „internetgalaxisba” (Castells 2001) született, ott magukat otthon érző fiatalok korábbitól jelentősen eltérő szokásainak, adottságainak, igényeinek, elvárásainak bemutatásával tesszük meg.

A téma jelentőségét nem szükséges magyarázni, a digitális kultúrára való áttérés következményeit mindannyiunknak érteni kell, de különösen fontos ez a gyermekeink, illetve az őket nevelők, a velük dolgozók számára (Wolf 2018).

\section{A digitális bennszülöttek megváltozott sajátosságai}

2020-ra elértük azt, hogy nem csupán fölösleges leírni, magyarázni Marc Prensky terminusát a „digitális bennszülöttek”-ről (ezt jellemzően nem is teszik már az elmúlt évek szakirodalmi forrásai), de a jelenségek, a sajátosságok is ismerősek lehetnek - még a laikusok számára is... A következőkben leírtak során ezért elsősorban azokra a jellegzetességekre fókuszáltunk, amelyek szorosabban kapcsolódnak a kultúrafogyasztáshoz, illetve az olvasáshoz.

Bár definíciót se nem idéznénk, se nem alkotnánk, egyfajta meghatározásként e generáció tagjaira érvényesnek tekintjük, hogy a virtuális térben immár nem időszakosan, hanem szinte kizárólagosan vannak jelen (Köpeczi-Bócz 2013). Az, hogy az elektronikus kommunikáció térnyerése milyen mértékben megváltoztatta az ember társas viszonyait és kognitív struktúráját, mostanra evidenciának számít (Lehmann 2017). Ráadásul az internetgalaxis még ehhez képest is drámai átalakulást hozott. A változás több területen is megfigyelhető. Egyrészt folyamatosan újabb és újabb médiumok jelennek meg, másrészt ezek sokkal több érzékszervet stimulálnak, mint a korábbiak (Lehmann 2017), ez pedig újabb változásokat generált, generál. Külön figyelmet érdemel az „exaptáció” fogalma. E jelenség meghatározóvá vált a 21 . század elején, a legkézenfekvőbb példa a mobiltelefon funkciójának megváltozása (a vonalas telefon „kiváltásától”, vagyis az egymással való beszélgetés eszközétől az internetezésig) (Lehmann 2017).

Érdekes, hogy Manuel Castells már 2001-ben - tehát még a közösségi oldalak „berobbanása" előtt - rámutatott a talán legfontosabb újdonságra: a társas kapcsolatok hálózatos jellegének erősítésére, erősödésére (Castells 2001). Gyorsan hozzátesszük: az nem számított újdonságnak, hogy a társas képességek módosulásai kulturális változásokhoz köthetők, erre a történelem során több alkalommal láthattunk már példát (Lehmann 2017). A hálózatok kapcsán meg kell emlékeznünk egy tipikusan 21. századi fogalomról, lehetőségről, a „crowdsourcing”-ről. Ez laikus, képzetlen - jellemzően internetes felhívással szervezett - munkaerő bevonását jelenti kutatásokba, adatok feldolgozásába. A csillagászattól a Higgs-bozon kereséséig mostanra milliós (!) nagyságrendű önkéntes segíti különböző kutatók munkáját. Jellemző példája ez a hálózatosodás erősségének is: tudniillik, hogy az egyéni teljesítmények nem csupán összeadódnak, annál jóval több lehetőség van e mögött (Lehmann 2017). Ilyen jellegű, jelentőségű, ily módon és céllal szervezett összefogásra korábban nem nagyon volt példa.

A „kiborgműveltség” (Rheingold 2012) azonban nem csupán a kognitív és társas képességek, a hálózatosodás terén hozott változást, de a kultúráról alkotott képünket is módosította. (A „kiborg” terminus itt az emberi és technológiai attribútumok keveredésére utal.) S különösen igaz ez azokra, akik már ebbe a közegbe születtek bele. Mit nevezünk, nevezhetünk kulturális értéknek? Melyek azok a művek, alkotások, amelyek egy közösség tagjai számára elvártan ismertek kellenek, hogy legyenek? Mit jelent egyáltalán a „műveltség” fogalma? Ezek a kérdések korábban is feszültségeket okozhattak különböző korosztályok között, de manapság még hangsúlyosabbak lettek, még inkább növelhetik a generációs szakadékot. 
Nem véletlenül fogalmazta meg még az egyébként optimista Maryanne Wolf is azt, hogy a digitális kultúra nem csupán a figyelemkoncentrációnkat, a tanulásunkat fenyegeti, de a szépség és az igazság felismerését is (Wolf 2018). Szerinte éppen ezért kulcskérdés, hogy meg tudjuk-e tanítani gyermekeinket a „mélyolvasásra”, amely többek között a kritikai gondolkodás vagy épp a problémamegoldás alapja is (Wolf 2018).

Márpedig a Z generáció tagjaira sok minden jellemző, de az elmélyülés kevéssé. Miközben soha nem látott mennyiségű információ megy át az agyukon, azokat kevéssé képesek rendszerezni, s így a tanulási, önálló ismeretszerző képességük is gyengébb (Gyarmathy-Kucsák 2012). Elvileg multitasking jellemzi őket, e párhuzamosság mögött azonban felszínesség is van.

\section{Kutatási adatok, eredmények, tapasztalatok}

A következőkben elsősorban a legfrissebb, a témában végzett reprezentatív kutatás eredményeire támaszkodunk. A Fővárosi Szabó Ervin Könyvtár az EFOP-3.3.3-VEKOP16-2016-00001 „Múzeumi és könyvtári fejlesztések mindenkinek” pályázati konstrukció keretében, „Az én könyvtáram” című kiemelt projekt részeként kérte fel a Psyma Hungary Kft.-t, hogy végezze el a felmérést - két alkalommal, 2017 és 2019 őszén. (A kutatás szakmai vezetője dr. Tóth Máté volt.) Elsősorban az utóbbi adatsort használjuk, néhol hivatkozva a két évvel korábbi eredményekre is.

Nyilván fontos adat az, hogy a fiatalok mennyi időt töltenek online, mennyire „szippantja be őket" a digitális világ. A 2017-es kutatás után Tóth Máté (2019) helyesen állapította meg, hogy csak akkor nem tünik nagynak a különbség a gyerekek és a felnőttek között e tekintetben, ha nem nézzük meg pontosabban a korosztályokat. Míg a kisiskolásoknak a harmada, a 10-14 éveseknek már közel a háromnegyede, a 14-17 éveseknek pedig több mint 90\%-a napi internetező. A felnőtteknél ugyanakkor - nem meglepő módon - a kor előrehaladtával fordított a tendencia.

„A gyerekek esetében (együtt nézve a 3-17 éves korosztályt) 5,2\% jelölte meg azt, hogy 10-20 percenként ránéz a telefonjára. Ez önmagában sem kevés, de a szám nyilván még ijesztőbb, ha figyelembe vesszük, hogy ebben a háromévesek is ott vannak - természetesen javítva az arányt. Másrészt aligha elhanyagolható az a tény, hogy tízéves kor alatt a szülők válaszoltak a gyerekek helyett, így nem azt tudtuk meg, hogy mennyit netezik a gyermek, hanem azt, hogy a szülő szerint mi a helyzet e téren." (Gombos 2019: 172)

Mivel a két adatfelvétel között mindössze két év telt el, s mert a minta sem volt azonos, többnyire nem vetjük össze egymással az eredményeket a változást keresve, itt azonban talán érdemes kivételt tenni, a különbség ugyanis látványos, $\mathrm{s}$ nem tűnik véletlenszerűnek. A korábbiakhoz képest a legaktívabb netezők aránya ugyanis közel duplájára nőtt, majdnem kilenc százalékra. Azoknak az aránya, akik 1-3 óránként lépnek föl a világhálóra, ugyanakkor jelentősen csökkent, 24-ről 14,6\%-ra.

Ha a másik szélsőséget nézzük meg, azt látjuk, hogy 2017-ben a megkérdezettek 26,6\%-a mondta azt, hogy soha nem használ netet. Ez 2019-re 18\%-ra csökkent, ami korántsem életszerütlen, hihetetlen változást mutat.

Érdemes külön is vizsgálni a korosztályokat az internethasználat terén. A „10-20 percenként ránéz a telefonjára (gyakorlatilag folyamatosan online van)”, kategóriában érthető módon - nem találunk 3-5 éves gyermeket. A 6-9 éveseknek majdnem 3\%-a tartozott ide, a 10-13 éveseknek 8,2\%-a, a 14-17 éveseknek pedig 22,4\%-a mondta ezt magáról. És ebben nincs már semmi meglepő, napjaink középiskolásainak, egyetemistáinak a többsége nem „fellép” az internetre, hanem permanensen ott van. (Többségük telefonja állandóan aktív internetkapcsolatra van beállítva.) Ezzel pedig az is együtt jár, 
hogy a kapott üzeneteket azonnal szeretnék megnézni, s fontosnak érzik az azonnali reagálást is.

Ha megnézzük azt, hogy milyen az életkori eloszlása azoknak, akik naponta vagy naponta többször használják a világhálót a barátokkal való kapcsolattartásra, azt látjuk, hogy már a 6-9 éveseknek is több mint 12\%-ára igaz ez, a 10-13 évesek majdnem felére (46,5\%), a 14-17 éveseknek pedig több mint háromnegyed részére. E mérésnek nem volt kifejezett célja a közösségi oldalak használatának részletes vizsgálata, de más kutatásból erről is vannak adataink. Ezek szerint a teljes magyar lakosság nagyjából négyötöde egyetlen napot sem hagy ki facebookozás nélkül. „A heavy, tehát intenzív felhasználók körében felülreprezentáltak a nők, az alacsonyabb iskolai végzettségűek és a 30 év alattiak, míg a light, tehát kevésbé intenzív felhasználóknál a férfiak, a felsőfokú végzettségűek, illetve a harmincasok felé billen a mérleg nyelve." (MTE 2016)

A megkérdezettek 49\%-a kommunikációs céllal, 40\% információszerzéshez, 43\% szórakozás céljából lép fel a közösségi oldalra (MTE 2016). Ez az általunk vizsgált korosztálynál a 2019-es mérésben némileg másképp mutat, az információszerzés nyilván kevésbé fontos számukra. A 14-17 évesek 13,5\%-a napi rendszerességgel használja a netet munkavégzéshez, illetve házifeladat-készítésnél (a 6-9 éveseknél ez 4,9\%, a 10-13 éveseknél 11,4\%). Meg kell jegyeznünk, hogy e kérdéseknél a válaszadók közül kihagytuk a 3-5 éveseket, látva, tudva, hogy az ő esetükben a kommunikáció, az információszerzés nem lesz ott a motivációs tényezők között. Az ugyanakkor figyelemreméltó adat, hogy az 1-2 óránként okoseszközt használók 6,6\%-a (!) 3-5 éves...

Ha azt nézzük meg, hogy van-e korosztályi különbség a világhálót játék céljából felkeresők között, azt tapasztaljuk, hogy a neten napi rendszerességgel játszók nagyjából negyede 6-9 éves, 38,4\% 10-13 éves, 35,8\%-uk középiskolás korú. A 6-9 éves korcsoportban a megkérdezettek valamivel kevesebb mint negyede, a 10-13, illetve 14-17 évesek 17-18\%-a mondta azt, hogy soha nem kapcsolódik ki internetes számítógépes játékkal.

Tanulságosnak ígérkezett megnézni az aktív (vagy éppen nagyon is inaktív) internetezők nemek szerinti megoszlását.

A legaktívabb kategóriában („folyamatosan online van”) nincs jelentős különbség, e csoport nagyjából 51\%-ában vannak fiúk. Látható - bár korántsem jelentős - különbséget a „naponta többször használja a netet” sorban látunk, itt többen vannak a fiúk, az arányuk 54,4\%. A lányok egyetlen kategóriánál vannak többen, az internetet nem használóknál az arányuk 51,6\%. Összességében azt mondható, hogy e téren már-már meglepő a kiegyenlítettség szintje $(\chi 2=3,702 ; \mathrm{df}=6 ; \mathrm{p}=0,717)$.

Jóval látványosabb a településtípus hatása a nethasználatra $(\chi 2=38,556 ; \mathrm{df}=18 ; \mathrm{p}=$ 0,003). Bár inkább a fővárosban várnánk, hogy felülreprezentált a folyamatosan online lévők száma, e kategóriában az ő arányuk 12,5\%, miközben a megyeszékhelyen élőké 16,9\%, a városiaké 41,2\%, a községekben lakóké pedig 29,4\%. A másik végletnél is szignifikáns eltérést látunk. A sohasem netező fiatalok 18,7\%-a él a fővárosban, 15\% megyeszékhelyen 34,8\% városban és 31,5\% községekben.

Olvasással kapcsolatos kutatásoknál szinte mindig előkerül a szülők iskolai végzettsége, és szinte minden esetben látjuk is e paraméter jelentőségét. Azt azonban ritkábban nézik meg, hogy az internetezés gyakoriságára van-e hatása például az apa iskolai végzettségének. Az adatok alapján nem úgy tűnik, hogy ez fontos tényező lenne. A legtöbbet internetező gyerekek 12\%-ánál az apának legfeljebb nyolc osztály a végzettsége, 11,3\%uknál főiskolai vagy egyetemi végzettséggel rendelkezik szülő. A másik szélsőségnél már látványosabb a különbség. Azoknál, akik nem jelennek meg a világhálón, 10\%-ban legfeljebb nyolc osztály az apa végzettsége, 19\%-nál főiskola vagy egyetem. Ugyanakkor az anya végzettsége mintha jelentősebb tényező lenne. A folyamatosan netezők nem egé- 
szen 10\%-ánál maximum nyolc osztályt végzett az anya, kicsit több mint 17\%-uknál látunk főiskolai, egyetemi végzettségű anyát. Hasonló a különbség a világhálótól távol maradók szüleinél, 13,6\%-nak maximum nyolcosztályos, 21,7\%-nál diplomás végzettségű az anya.

Ennél mintha egyértelműbb lenne a hatása annak, hogy a megkérdezett gyermekek egy- vagy kétszülős háztartásban élnek-e. Azok a fiatalok, akik egyszülős családban nőnek fel, láthatólag több időt töltenek el a digitális világban. Több mint a tizedük $(11,5 \%$ uk) folyamatosan online van, a kétszülős gyermekeknél ez az arány 8,7\%.

A korábbi, 2017-ben elvégzett kutatás egyik újdonsága az volt, hogy rákérdeztünk az internethasználattal kapcsolatos szokásokra. Az akkor nyert adatokat arra is fölhasználtuk, hogy összefüggést keressünk a digitális kultúra iránt különböző mértékben elkötelezett gyerekek és az olvasási kedv között. Az eredmények egyértelműek voltak:

„Az internethasználat (telefonhasználat) és az olvasási kedv összefüggése egészen egyértelműen megmutatkozik az eredményekből. Azok közül, akik folyamatosan online vannak, 57,7\% egyetlen könyvet sem olvasott el a megelőző egy évben! Ez messze a legmagasabb arány, hiszen a netet egyáltalán nem használók között is »csupán « 44,4\% tartozik a nem olvasók kategóriájába. A netre 1-2 óránként ránézők között már jóval kevesebben vannak a nem olvasók, $28,7 \%$ válaszolta ezt.

1. táblázat: Az internethasználat és az olvasási kedv összefüggése (2017)

\begin{tabular}{|c|c|c|c|c|c|}
\hline \multirow[b]{2}{*}{$\begin{array}{l}\text { Milyen gyakran szokott internetet } \\
\text { (számítógépen, laptopon, táblagé- } \\
\text { pen vagy okostelefonon keresztül) } \\
\text { használni: }\end{array}$} & \multicolumn{5}{|c|}{$\begin{array}{l}\text { Elfoglaltságai mellett - a tankönyvön és az iskolai kö- } \\
\text { telező olvasmányokon kívül - olvas-e könyveket (vagy } \\
\text { ha még nem tud olvasni, akkor olvasnak-e fel neki) }\end{array}$} \\
\hline & $\begin{array}{c}\text { Egyet } \\
\text { sem } \\
\text { olvasott } \\
\text { az utób- } \\
\text { bi } 12 \\
\text { hónap- } \\
\text { ban }\end{array}$ & $\begin{array}{c}1-3 \\
\text { könyvet } \\
\text { elolva- } \\
\text { sott az } \\
\text { utóbbi } \\
12 \text { hó- } \\
\text { napban }\end{array}$ & $\begin{array}{l}\text { legalább egyet } \\
\text { negyedéven- } \\
\text { ként }\end{array}$ & \begin{tabular}{|} 
havon- \\
ként \\
legalább \\
egy \\
könyvet \\
elolva- \\
sott?
\end{tabular} & $\begin{array}{c}\text { nem } \\
\text { tudja } \\
\text { nem } \\
\text { vála- } \\
\text { szol }\end{array}$ \\
\hline $\begin{array}{l}\text { 10-20 percenként ránéz (gyakorla- } \\
\text { tilag folyamatosan online van) }\end{array}$ & $57,7 \%$ & $24,4 \%$ & $14,1 \%$ & $3,8 \%$ & $0,0 \%$ \\
\hline 1-2 óránként & $28,7 \%$ & $41,1 \%$ & $21,7 \%$ & $7,0 \%$ & $1,6 \%$ \\
\hline naponta & $28,0 \%$ & $42,4 \%$ & $18,6 \%$ & $8,7 \%$ & $2,3 \%$ \\
\hline naponta többször & $33,5 \%$ & $33,2 \%$ & $20,1 \%$ & $10,5 \%$ & $2,6 \%$ \\
\hline hetente többször & $23,9 \%$ & $39,8 \%$ & $22,9 \%$ & $11,9 \%$ & $1,5 \%$ \\
\hline hetente egyszer-kétszer & $28,3 \%$ & $26,1 \%$ & $27,2 \%$ & $14,1 \%$ & $4,3 \%$ \\
\hline ennél ritkábban & $33,3 \%$ & $11,1 \%$ & $0,0 \%$ & $44,4 \%$ & $11,1 \%$ \\
\hline nem szokott internetezni & $44,4 \%$ & $22,8 \%$ & $13,4 \%$ & $17,1 \%$ & $2,3 \%$ \\
\hline
\end{tabular}

Érdekes dolgot tapasztalhatunk, ha azt nézzük meg, kik olvasnak sokat a netezők közül. 
A havonta legalább egy kötetet befejezők 44,4\%-a egy hónapban kevesebb mint egykét alkalommal lép föl a világhálóra. Akik kicsivel gyakrabban teszik ezt, azoknak pontosan a negyede jelölte meg azt, hogy »elit olvasónak « számítanak (vagyis évi átlagban 12 könyvet olvasnak el). Érdemes még megemlítenünk azokat, akik egyáltalán nem neteznek, mert közöttük - talán meglepetésre - elég sokan, 17,1\% tartozik a legaktívabb olvasói csoportba." (Gombos 2019: 174-175)

A megismételt kutatás számunkra egyik legizgalmasabb kérdése az volt, hogy újra kimutatható lesz-e a két évvel korábban látott összefüggés, esetleg bizonyítható lesz-e a sejthetően tovább romló helyzet, vagyis az, hogy a netfüggők egyre nagyobb része fordul el a könyvkultúrától.

A 2019-es vizsgálat számai nem sokban különböznek az előzőtől, a netfüggés és az olvasási motiváció kapcsolata ezúttal is kirajzolódik, sőt, egyértelműen megmutatkozik az is, hogy negatív irányban van elmozdulás.

2. táblázat: Az internethasználat és az olvasási kedv összefüggése (2017)

\begin{tabular}{|l|c|c|c|c|}
\hline \multicolumn{1}{|c|}{} & \multicolumn{3}{|c|}{$\begin{array}{c}\text { Elfoglaltságai mellett - a tankönyvön és az iskolai kötelezö olvasmá- } \\
\text { nyokon kívül - olvas-e könyveket }\end{array}$} \\
& \multicolumn{3}{|c|}{ (vagy ha még nem tud olvasni, akkor olvasnak-e fel neki) } \\
\hline & $\begin{array}{c}\text { egyet sem olva- } \\
\text { sott az utóbbi } \\
12 \text { hónapban }\end{array}$ & $\begin{array}{c}\text { elolvasott az } \\
\text { utóbbi } 12 \text { hó- } \\
\text { napban }\end{array}$ & $\begin{array}{c}\text { legalább egyet } \\
\text { negyedévenként }\end{array}$ & $\begin{array}{c}\text { könyvet elolva- } \\
\text { legatt }\end{array}$ \\
\hline $\begin{array}{l}\text { 10-20 percenként ránéz } \\
\text { (gyakorlatilag folyama- } \\
\text { tosan online van) }\end{array}$ & $62,3 \%$ & $23,8 \%$ & $8,5 \%$ & $5,4 \%$ \\
\hline egy-két óránként & $52,6 \%$ & $22,3 \%$ & $13,7 \%$ & $11,4 \%$ \\
\hline naponta többször & $47,7 \%$ & $31,0 \%$ & $13,4 \%$ & $8,0 \%$ \\
\hline naponta & $47,7 \%$ & $31,0 \%$ & $13,4 \%$ & $8,0 \%$ \\
\hline hetente többször & $26,2 \%$ & $32,4 \%$ & $24,1 \%$ & $17,2 \%$ \\
\hline hetente egyszer-kétszer & $24,7 \%$ & $27,3 \%$ & $18,2 \%$ & $29,9 \%$ \\
\hline $\begin{array}{l}\text { havonta egy-két alka- } \\
\text { lommal }\end{array}$ & $52,9 \%$ & $35,3 \%$ & $5,9 \%$ & $5,9 \%$ \\
\hline $\begin{array}{l}\text { nem szokott internetez- } \\
\text { ni }\end{array}$ & $40,2 \%$ & $21,2 \%$ & $12,7 \%$ & $25,9 \%$ \\
\hline
\end{tabular}

Ahogy a táblázat első sorából kiolvasható, immáron a folyamatosan online lévő fiatalok közel kétharmada nem vesz könyvet a kezébe. Igaz ugyanakkor, hogy a sokat olvasók aránya 3,8-ról 5,4\%-ra nőtt közöttük.

Legutóbb is érdekes volt látni azt, hogy a digitális kultúrától távol maradók között meglehetősen nagy arányban vannak kifejezetten sokat olvasók. Akkor ez 17 százalék volt, most már közel 26! Vagyis azoknak, akik saját bevallásuk szerint sohasem lépnek föl a világhálóra, több mint negyede kifejezetten sokszor, gyakran választja a könyvet kikapcsolódásul.

További érdekes részleteket tudhatunk meg, ha tovább bontjuk a 2019-es adatokat, ha külön megnézzük a 9-13, illetve a 14-17 éves korosztályt.

Nézzük először a fiatalabbakat. 
3. táblázat: Az internethasználat és az olvasási kedv összefüggése 9-13 éveseknél (2019)

\begin{tabular}{|l|r|r|r|r|}
\hline \multicolumn{1}{|c|}{ 9-13 évesek } & \multicolumn{3}{|c|}{ Elfoglaltságai mellett - a tankönyvön és az iskolai kötelezó olvasmányokon } \\
kívül - olvas-e könyveket
\end{tabular}

Ami feltűnő lehet az előző táblázathoz képest, az az, hogy itt a sohasem internetezők között magasabb a nem olvasók aránya, ugyanakkor lényegesen alacsonyabb a sokat olvasóké is.

Vajon mi a helyzet egy korcsoporttal feljebb?

4. táblázat: Az internethasználat és az olvasási kedv összefüggése 14-17 éveseknél (2019)

\begin{tabular}{|c|c|c|c|c|}
\hline \multirow[t]{2}{*}{ 14-17 évesek } & \multicolumn{4}{|c|}{$\begin{array}{l}\text { Elfoglaltságai mellett - a tankönyvön és az iskolai kötelező olvasmányokon } \\
\text { kívül - olvas-e könyveket } \\
\text { (vagy ha még nem tud olvasni, akkor olvasnak-e fel neki) }\end{array}$} \\
\hline & $\begin{array}{l}\text { egyet sem olva- } \\
\text { sott az utóbbi } 12 \\
\text { hónapban }\end{array}$ & $\begin{array}{l}\text { 1-3 könyvet elol- } \\
\text { vasott az utóbbi } \\
12 \text { hónapban }\end{array}$ & $\begin{array}{c}\text { legalább egyet } \\
\text { negyedévenként }\end{array}$ & $\begin{array}{l}\text { havonként lega- } \\
\text { lább egy könyvet } \\
\quad \text { elolvasott }\end{array}$ \\
\hline $\begin{array}{l}\text { 10-20 percenként } \\
\text { ránéz (gyakorlati- } \\
\text { lag folyamatosan } \\
\text { online van) }\end{array}$ & $62,5 \%$ & $26,1 \%$ & $6,8 \%$ & $4,5 \%$ \\
\hline naponta többször & $53,0 \%$ & $24,6 \%$ & $14,8 \%$ & $7,6 \%$ \\
\hline naponta & $56,1 \%$ & $21,1 \%$ & $17,5 \%$ & $5,3 \%$ \\
\hline hetente többször & $50,0 \%$ & $28,6 \%$ & $21,4 \%$ & $0,0 \%$ \\
\hline $\begin{array}{l}\text { hetente egyszer- } \\
\text { kétszer }\end{array}$ & $100,0 \%$ & $0,0 \%$ & $0,0 \%$ & $0,0 \%$ \\
\hline $\begin{array}{l}\text { nem szokott in- } \\
\text { ternetezni? }\end{array}$ & $100,0 \%$ & $0,0 \%$ & $0,0 \%$ & $0,0 \%$ \\
\hline
\end{tabular}

Az utolsó három sor százalékos adatai „gyanúsan kerekek”, s az utolsó két esetében ennek meglehetősen egyszerű magyarázata van: e korcsoportban a megkérdezett 222 fiatal közül mindössze egy mondta azt, hogy hetente egyszer-kétszer és mindössze kettő 
azt, hogy sohasem használ internetet. Egyrészt e sorok eredményeit tehát nem érdemes figyelembe venni, másrészt ez arra is utal, hogy e sorokban a még fiatalabbak között találunk nagyobb elemszámot.

2017-ben nem vizsgáltuk, ezúttal viszont meg tudjuk mutatni, hogy van-e összefüggés a könyvtári tagság és az interneten töltött idő között.

A folyamatosan online lévők 48\%-a mondta azt, hogy soha nem volt könyvtári tag, majdnem 17\%-uk jelenleg is regisztrálva van egy bibliotékában, valamivel több mint $2 \%$-uk többen is.

Az internetet nem használóknak éppen a háromnegyede nem volt még soha beiratkozva, mintegy ötödük viszont jelenleg is tag, kicsit több mint 2,5\%-uk több könyvtárba is jár. Ezek a számok önmagukban nem meglepőek, hiszen régóta tudjuk azt, hogy könyvtárba azok járnak, akiket a kultúra más területei is érdekelnek, így az sem furcsa, hogy aki még az internetre sem lép föl, azok nagyobb része könyvtárba sem megy el. Csakhogy a korábbi táblázatok szerint e klaszterben viszonylag nagy arányban vannak sokat olvasók. Ezek szerint azonban ők más forrásból szerzik be a könyveket.

A két évvel ezelőtti kutatás egyik érdekes eredménye volt az, hogy nyilvánvalóan átalakult a gyerekek, fiatalok könyvízlése, már ami a műfajokat illeti. Ahogy azt annak idején hosszabban elemeztük is (Gombos 2019), látványos a fantasztikus műfajok (sci-fi, fantasy) előretörése, illetve - nem meglepő módon - a képregény megjelenése mindegyik korosztály olvasói palettáján.

5. táblázat: A 3-17 évesek által olvasott müfajok (2017)

\begin{tabular}{|l|l|l|l|l|l|}
\hline & $3-5$ évesek & $6-9$ évesek & $10-13$ évesek & $14-17$ évesek & Összesen \\
\hline 1. mesék, meseregények & $82,86 \%$ & $76,66 \%$ & $32,51 \%$ & $8,50 \%$ & $47,27 \%$ \\
\hline 2. versek, gyermekversek & $58,42 \%$ & $41,03 \%$ & $13,65 \%$ & $8,52 \%$ & $28,00 \%$ \\
\hline 3. kalandregények & $0,72 \%$ & $13,27 \%$ & $41,44 \%$ & $44,53 \%$ & $27,07 \%$ \\
\hline 4. szórakoztató regények & $3,21 \%$ & $14,99 \%$ & $37,72 \%$ & $41,85 \%$ & $26,25 \%$ \\
\hline 5. képeskönyvek, lapozók & $60,00 \%$ & $37,99 \%$ & $12,16 \%$ & $0,00 \%$ & $24,77 \%$ \\
\hline $\begin{array}{l}\text { 6. mondókák (ringatók, } \\
\text { ölbeli játékok) }\end{array}$ & $53,76 \%$ & $30,96 \%$ & $7,69 \%$ & $0,00 \%$ & $20,47 \%$ \\
\hline 7. képregények & $11,83 \%$ & $22,85 \%$ & $24,07 \%$ & $19,71 \%$ & $20,27 \%$ \\
\hline $\begin{array}{l}\text { 8. tudományos, ismeret- } \\
\text { terjesztö müvek }\end{array}$ & $2,51 \%$ & $10,81 \%$ & $26,98 \%$ & $30,83 \%$ & $19,11 \%$ \\
\hline 9. fantasy & $0,00 \%$ & $6,88 \%$ & $24,32 \%$ & $32,60 \%$ & $17,33 \%$ \\
\hline 10.klasszikus regények & $1,08 \%$ & $4,41 \%$ & $19,06 \%$ & $32,85 \%$ & $15,51 \%$ \\
\hline $\begin{array}{l}\text { 11.tini (szerelmes, roman- } \\
\text { tikus regények) }\end{array}$ & $0,00 \%$ & $4,67 \%$ & $20,60 \%$ & $29,93 \%$ & $15,00 \%$ \\
\hline 12.találós kérdések & $13,57 \%$ & $19,41 \%$ & $14,64 \%$ & $7,52 \%$ & $13,78 \%$ \\
\hline 13.történelmi regények & $0,36 \%$ & $3,69 \%$ & $17,87 \%$ & $27,01 \%$ & $13,26 \%$ \\
\hline 14.sport & $0,00 \%$ & $7,11 \%$ & $17,62 \%$ & $18,93 \%$ & $11,85 \%$ \\
\hline 15.sci-fi & $0,00 \%$ & $2,21 \%$ & $13,90 \%$ & $22,38 \%$ & $10,47 \%$ \\
\hline 16.hobbi & $0,72 \%$ & $3,44 \%$ & $13,15 \%$ & $16,55 \%$ & $9,13 \%$ \\
\hline 17.krimik & $0,00 \%$ & $1,72 \%$ & $6,70 \%$ & $19,71 \%$ & $7,67 \%$ \\
\hline 18.vámpírregények & $0,00 \%$ & $1,47 \%$ & $7,18 \%$ & $14,11 \%$ & $6,20 \%$ \\
\hline 19.horror & $0,00 \%$ & $0,98 \%$ & $3,47 \%$ & $10,19 \%$ & $3,99 \%$ \\
\hline 20.egyéb & $2,14 \%$ & $1,47 \%$ & $1,73 \%$ & $2,67 \%$ & $2,00 \%$ \\
\hline & & & & & \\
\hline
\end{tabular}

2019-ben ehhez képest alig látunk változást, szignifikáns eltérés nincs is. De ez a terület nem is változik ilyen gyorsan, s ez esetben a kétszeri, két éven belüli mérés inkább 
arra volt jó, hogy az adatok „erősítsék egymást”, vagyis hogy még egyértelműbb legyen a jelenség, amelyre utalnak.

\section{6. táblázat: A gyerekek által olvasott múfajok (2019)}

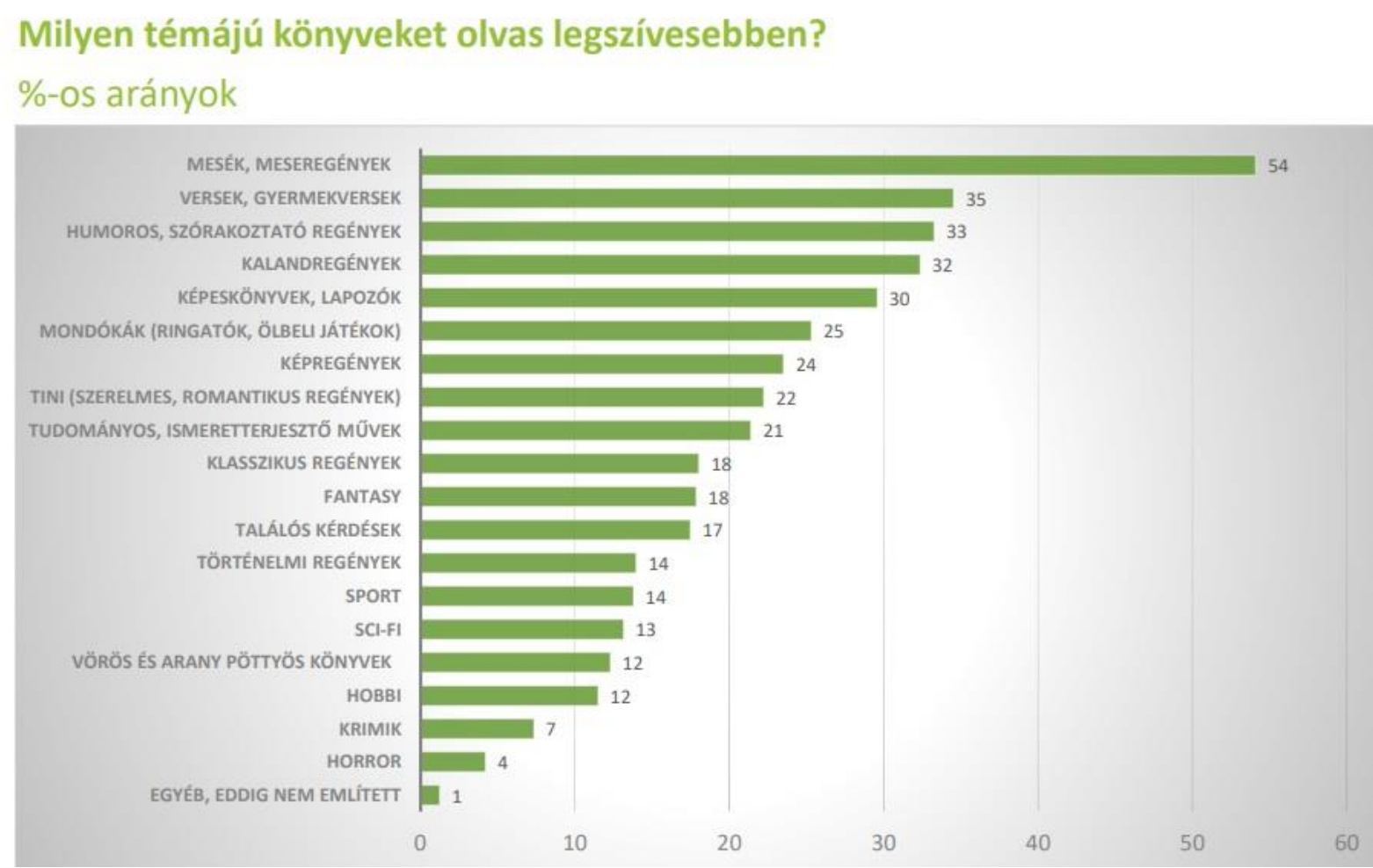

Érdekes kérdésnek tűnt, hogy van-e, kimutatható-e a kapcsolat a digitális világhoz igazán kötődők és bizonyos műfajok között. A meglévő adatokat úgy szűrtük le, hogy csak a tíz évnél idősebbeket néztük meg, s közülük is azokat, akik nagyon sokat, illetve alig vagy egyáltalán nem interneteznek.

Az első fontos észrevételünk az volt, hogy e korcsoportban a fantasy műfajt kedvelők 96,4\%-a folyamatosan online van. Ezzel párhuzamosan azoknak, akik soha nem vagy csak ritkán lépnek föl a világhálóra, mindössze 3,6\%-a olvas fantasyt.

Még erősebb az összefüggés a sci-fi-olvasás és az internetezés között. A műfajt olvasók 98,3\%-a (!) permanens internetező. Ugyanakkor a nettől távol maradók 6,7\%-a is megjelölte a tudományos-fantasztikus regényeket.

Amikor hasonló módon kerestünk kapcsolatot az internethasználat, illetve a képregények, majd a klasszikus regények olvasása között, az eredmények azt mutatták, hogy nincs ilyen összefüggés.

\section{Új jelenségek a 21. század könyvkultúrájában}

Az internetkultúrának természetesen nem csupán negatív hatásai vannak az olvasásra, az olvasási kedvre nézve. Miközben mérhető például a Facebook (vagy általában az „always on lét”) negatív hatása az irodalomolvasásra, vannak olyan közösségi oldalak, amelyeknek tagjait éppen az olvasás, a könyvek szeretete hozta össze. Ráadásul akár egészen komoly létszámú csoport jöhet össze egy-egy ilyen téma kapcsán.

A Moly.hu oldala 2008-ban jött létre, s bár sokan afféle kulturális lexikonként tartják számon, az alapító szándéka szerint „elsősorban kommunikációs felület, és csak azután a Wikipédiára hasonlító lexikon”. (Szedlák 2010) 
„Az oldal nagyon széles szolgáltatási palettát kínál, így a felhasználási lehetőségek köre is igen tág. A használó elkészítheti saját virtuális könyvespolcát, értékelheti az olvasott könyveket, figyelheti mások tevékenységét, tehet megjegyzéseket, írhat karcokat, cseveghet ismerősökkel és ismeretlenekkel. Hasonlóan más web 2.0 szolgáltatásokhoz, az oldal csak a kereteket szabja meg, a tartalmat és a használat mikéntjét a felhasználók írják, illetve határozzák meg." (Tóth 2011)

Sokat elárul a site (és a közösség) működésének sikerességéről, hogy mostanra (a Moly.hu oldalán olvasható statisztikai adatok alapján) közel 200 ezer regisztrált tagjuk van, több mint 360 ezer könyvről írtak a felhasználók, majdnem egymillió idézetet válogattak, közel két és fél millió értékelés mellett immár a kilencmilliót közelíti a hozzászólások száma (Moly.hu 2019). Hogy ez a „műfaj” éppen ebben az évtizedben lett ennyire sikeres, valószínúleg nem véletlen. A horizontális kapcsolatok kiteljesedése - amelynek egyik fő okozója a közösségi oldalak, illetve az okostelefonok elterjedése - a központi kontroll gyengülését és az önszerveződések erősödését hozta magával (Lehmann 2017).

„Az elképzelést, hogy afféle intellektuális fórumként működjön a hely, ahol a beszélgetések apropóját konkrét regények, könyvek adják, igazolta az élet. Ráadásul nemcsak időtöltésnek jó a Moly.hu látogatása, arra, hogy más, többnyire hozzánk hasonló olvasói ízlésű felhasználóval megosszuk a véleményünket, élményeinket. A tapasztalatok azt mutatják, hogy az oldal segítséget is jelenthet, információkat szolgáltathat, amikor utánanéznénk, -olvasnánk egy műnek. Természetesen nem objektív kritikákat találunk itt, de ezt nem is állítja senki a „szerzők” közül. Másrészt akár többtucatnyi olvasó meglátásai, értékelései közül válogathatunk, például úgy, hogy megkeressük azt, azokat, akinek, akiknek korábbi ítéleteivel, véleményével egyetértettünk. Az oldal jól kommunikál felhasználói olvasói blogjaival, illetve más közösségi oldalakkal, ami az olvasáskultúra terjesztése szempontjából sem elhanyagolható tényező. Viszonylag új jelenség az olvasói influencerek megjelenése: őket néha éppen a kiadók inspirálják, promóciós célokra is használva írásaikat." (Gombos 2019: 177)

„Egészen más jellegű összetartó erő, s jellemzően a 21. században csúcsra jutó műfaj a fanfiction. A »rajongók által továbbgondolt és írt történetek, valamilyen irodalmi mű folytatásai« (Kerekes-Kiszl 2018: 88) hallatlanul népszerűek világszerte. Egy-egy történet lelkes hívei nemcsak továbbgondolják kedvenc műveiket, de meg is osztják azokat másokkal - szándékoltan ilyen céllal létrehozott oldalakon. Bár a műfaj korábban is létezett, természetesen jelentősen növelte a népszerűségét az internet elterjedése. A korábban nyomtatva kézről kézre adott szövegek így, elektronikus formában pillanatok alatt tízezrekhez juthattak el." (Gombos 2019: 178)

„Az ilyen honlapok célja éppen az, hogy a kreatívabb rajongók visszajelzéseket kaphassanak, fejlődjenek, és egyre hosszabb és élvezhetőbb műveket tárhassanak a fanatikus olvasók elé. Egyes portálok fórumot is biztosítanak, amelyben lehetőség nyílik az ismerkedésre, az íróval való kommunikációra és a történettel kapcsolatos egyéb információk megszerzésére." (Endes 2011)

Érdekes, hogy a fanfictionök születése, terjesztése mögött nincs pénzszerzési szándék. (A publikálásra létrehozott oldalak általában nyilatkoztatják a szerzőket arról, hogy anyagi haszonszerzésre nem törekszenek a szövegekkel.) A motiváció egész más, ez is a digitális kultúra terjedésének hozadéka. Azé a kultúráé, amelyre az individuális médiafogyasztással szemben a hálózatba szervezett befogadói közösségek jellemzőek inkább (Nitzuko Itót idézi: Andok-Hevér 2017). Másrészt az is fontos tényező, hogy a web 2.0 egyik legfőbb sajátossága az alkotó és befogadó közötti határvonal elmosódása (Lehmann 2017). 
Elgondolkodtató, hogy a legnagyobb nemzetközi oldalaknak (például a Fanfiction.netnek) milliós felhasználói köre van. Magyarországon talán a 15 éve alapított Merengő a legnagyobb hatású site, első 12 évük alatt húszezresre duzzadt taglétszámmal. A közzétett írások száma is húszezer körül jár, kritikából pedig több mint félmillió jelent már meg (Andok-Hevér 2017).

A korábbi kutatási adatok fényében meglepőnek tűnhetne, ma már kevésbé az, hogy a Merengő aktív látogatóinak nagyon nagy többsége nő. A regisztrált tagok többnyire fiatalok, az átlagéletkor pedig 24 év körüli. A legfontosabb közös téma - s valószínúleg a hazai fanfiction-mozgalom „berobbantója” - a Harry Potter-sorozat, jelenlétüket pedig e közösségben (mely elsősorban virtuális, a személyes találkozókon a tagok kis része vesz részt, noha fontosnak tartják azt) a szórakozás, kikapcsolódás motiválja (Andok-Hevér 2017).

\section{Összegzés}

A digitális kultúra megjelenése, korunk változásai kapcsán sokan panaszkodnak, sokan festenek sötét képet, vizionálják a Gutenberg-galaxis bukását s általában a kultúra valamiféle „elszegényedését”, sivárabbá válását. Hogy valóban így lesz-e, aligha tudja ezt bárki teljes bizonyossággal megjósolni, mindenesetre a jelenség sokkal összetettebb annál, hogy sommás véleményt, jóslatokat fogalmazzunk meg. Ami pedig a kultúraváltást illeti, ezzel kapcsolatban pontosnak gondoljuk Lehmann Miklós meghatározását:

„A kultúra nem pusztán az ember környezetének egyfajta tükröződése, hanem magas szintű absztrakció, amely az ember élővilágától csaknem függetlenül értelmezhető, s mint ilyen, meghatározza annak módozatait, miként látja az ember saját természeti és társas világát, milyen kognitív stratégiákat alkalmaz, miként gondolkodik, és hogyan szervezi meg mindennapi életét. Ebben az elméleti keretben a technika helye a kulturális termékek sorában van..." (Lehmann 2017: 17) Vagyis mindez nemcsak azt jelenti, hogy a technológiai lehetőségek hatnak a kultúrára is, új kulturális termékek megjelenését eredményezve (Lehmann 2017), de azt is, hogy mindezek az újdonságok részei a(z új) kultúrának, amelyről innentől másképp kell gondolkodnunk.

Ugyancsak gyakori panasz, sötét jóslat, hogy maga a könyvkiadás is rossz irányba halad, valamiféle értékesebbtől valamilyen szempontból értéktelenebb felé. E felvetés megint csak rossz megközelítésből indul el. Egyetértünk, s nem csupán az olasz helyzetre érezzük találónak azt, hogy „a könyvkiadás mindig is az értékesítési piac lehetséges határáig nyomult" (Baricco 2019: 116). Vagyis egyértelműen a vásárlóerő, az érdeklődés hat vissza a piacra, a kiadásra, s kevésbé jellemző (bár erre is van példa), hogy az eladó teremti meg magának vagy befolyásolja ízlésében a potenciális befogadókat.

Ez azt is jelenti, hogy egy adott társadalomban az irodalmi nevelés, az irodalom, az olvasás presztízse sokkal fontosabb tényező tud lenni egyéb aspektusoknál.

Népszerű kesergés az is, hogy kortárs, kevésbé értékes (önmagában is érdekes, hogy ez mit jelent...) művek kiszorítják a piacról s pláne az iskolából a klasszikusokat. Ahogy korábban is utaltunk rá, ez részben nem vagy nehezen befolyásolható jelenség, másrészt tapasztalhatjuk, hogy a jelen népszerü irodalma nem a klasszikusok rovására terjeszkedik (Baricco 2019). Sokkal jellemzőbb, hogy a kortárs irodalmat szívesen olvasó fiatalok később értő, akár rajongó olvasói lesznek korábbi szerzőknek, korábbi műveknek. Immáron magyar kutatási eredmények is bizonyítják, hogy a diákokhoz időben közelebb álló múveknek milyen pozitív hatása van az olvasási kedvet illetően (Józsa-Fiala-Józsa 2017).

Mindazonáltal kétségkívül szemtanúi vagyunk olyan változásoknak, amelyek egy részét talán nem szabad tétlenül nézni. „A ma könyveket vásárlók többsége nem olvasó.” 
(Baricco 2019: 120) A digitális bennszülöttek egy része olyan szövegekre kíváncsi, amelyek alapján film készült (vagy amely film alapján készült), illetve jellemző, hogy így-úgy hírnevet szerzett celebek (élet)történeteit falják. Olyan könyveket olvasnak, amelyekhez a „használati utasítás” nem könyvekben található meg (Baricco 2019). Ugyanakkor sohasem látott népszerűsége van bizonyos műfajoknak - ahogy a kutatási adatok alapján leírtuk, a sci-finek, a fantasynek soha nem volt még ennyi rajongója, de új műfajok is megjelentek, elég csak a fanfictiont említeni.

Természetesen az a jelenség, hogy az internetkultúra legaktívabb tagjai (és ők most már többen vannak, mint a passzívak) elfordulnak a Gutenberg-galaxistól, nem örvendetes tény. De a generációra jellemző más sajátosságok (lásd a köreikben nagyon népszerű témákat, műfajokat) figyelembevételével korántsem tűnnek „menthetetlennek” a digitális bennszülöttek. A „hogyan” - egyébként nyilván roppant fontos - kérdésre azonban nem itt, nem nekünk kell választ adni.

\section{Irodalom}

Andok Mónika - Hevér Kinga (2017): Kulturális konvergencia: a Merengő nevű fanfiction oldal elemzése. In: Média - Történet - Kommunikáció, 12(1), 31-44.

Baricco, Alessandro (2019): Barbárok. Bp.: Helikon

Castells, Manuel (2001): The Shallows : What the Internet Is Doing to Our Brains. New York: Norton

Csernoch Mária, dr. (2018): A digitális bennszülött és a multitasker mítosza. [online] In: A Digitális Esélyegyenlőség Alapítvány oldala

<URL: https://www.deaweb.hu/deagora/digitalis-iranytu/a-digitalis-bennszulott-es-amultitasker-mitosza [2019. 12. 22.]

Endes Ilona (2011): A fanfiction mint alternatív történetgyár. [online] In: A Kulter oldala cop. 2011. 02. 28. <URL: http://kulter.hu/2011/02/a-fanfiction-mint-alternativ-

tortenetgyar/[2019.01. 10.]

Gombos Péter (2019): A digitális generáció olvasási szokásai - a 2017-es reprezentatív olvasásfelmérés tapasztalatai. In: Barátné Hajdu Ágnes - Béres Judit szerk.: Olvasásfejlesztés könyvtári környezetben. (Módszertani kötetek 2). Bp.: Fővárosi Szabó Ervin Könyvtár pp. 149-191.

Gombos Péter (2019): Olvasás és közösségfejlesztés Magyarországon. Sághi Ilona szerk.: Partnerségben a könyvtárral. Bp.: Szabadtéri Néprajzi Múzeum - Múzeumi Oktatási és Módszertani Központ - NMI Művelődési Intézet Nonprofit Közhasznú Kft. - Országos Széchényi Könyvtár pp. 173-179.

Gyarmathy Éva - Kucsák Julianna (2012): A digitális bennszülöttek képességprofilja : A mérési eljárások, a linearitás és a hagyományos iskolai tanítás alkonya. Iskolakultúra 22(9), 43-53.

Józsa Krisztián - Fiala Szilvia - Józsa Gabriella (2017): A klasszikus és a kortárs szövegek fel-dolgozásának hatása az olvasás affektív tényezőire. Anyanyelv-pedagógia 10(1), 1927.

Kerekes Pál - Kiszl Péter (2018): Magyar irodalom a világhálón : Szabadon elérhető magyar nyelvü szöveggyüjtemények. Bp: ELTE

Köpeczi-Bócz Tamás (2013): Oktatás a globális médiakörnyezetben : Ki neveli a gyermeket? In: Bárdos Jenő - Kis-Tóth Lajos - Racsko Réka szerk.: Új kutatások a neveléstu- 
dományban : Változó életformák, régi és új tanulási környezetek. Bp.: Líceum Kiadó pp. 135-152.

Lehmann Miklós (2017): A digitális elme : Hálózat és pedagógia. Bp: ELTE TÓK MTE - Magyarországi Tartalomszolgáltatók Egyesülete (2016): Hogyan viselkednek a magyar Facebookozók? Itt vannak a legújabb trendek és eredmények. In: az MTE honlapja [online] cop. 2016. 02.11. [2019.12.28.] <URL: http://mte.hu/_magyar_facebook_trendek/ Rheingold, Howard (2012): Mind Amplifier : Can Our Digital Tools Make Us Smarter? Ted Conferences, Kindle Edition

Szedlák Á. (2010): Moly.hu: könyves közösségi oldal saját zenekarral. In: Origo, [online] cop. 2010.04.14. [2012. 09. 26.] <URL:

http://www.origo.hu/techbazis/internet/20100410-molyhu-konyves-kozossegi-oldalsajat-zenekarral.html>

Tóth Máté (2019): A 3-17 éves korosztály olvasási szokásai egy országos reprezentatív felmérés eredményei. In: Béres Judit szerk.: A könyvtárhasználat és az információkeresés fejlesztése. (Módszertani kötetek 4.) pp. 261-316.

Tóth Máté (2011): A Moly.hu mint virtuális találkozóhely. Tudományos és Müszaki Tájékoztatás, 58(8)

<URL: http://tmt-archive.omikk.bme.hu/show_news.html@id=5534\&issue_id=529.html Wolf, Maryanne (2018): Reader, Come Home : The Reading Brain in a Digital World.New York: Harper Collins.

\section{SUMMARY}

\section{Digital natives' zest for reading, attitude to reading in light of the surveys of 2017 and 2019}

Even though they show interesting data not only for experts, representative reading surveys are not conducted frequently in Hungary. There is a very literal reason for that: a research like this requires significant resources. That is why the fact that we could do a research like that twice during the past three years is of vital importance and for other reasons as well.

Our aim with our study was not to present the results of the last survey in as many details as possible or to analyse them. We wanted to take a closer look at a special field. We highlighted those data of the research which could or can support the assumption that the children of the digital era read different things in a different way.

First of all we describe the cluster with the help of research literature resources, which are characterised later by the data of the survey as well. As 3-5 years meant serious differences between the age groups during the past twenty-twenty-five years, we could rely only on up-to-date sources, mainly the ones after 2010.

After the theoretical background we describe briefly the most important parameters of the research conducted within the framework of the application of the Metropolitan Ervin Szabó Library, then we analyse the data gained here. (Several times we compare the data to earlier ones of the same project, or to surveys done and presented by others.)

As we wanted not only to share the results of a representative research, we present two characteristically 21st century "phenomena” as well: the operation, the appearance of online communities of book lovers and of fanfiction appearing mainly online in the culture of our everyday life.

Kulcsszavak: reading survey, digital natives, fanfiction 